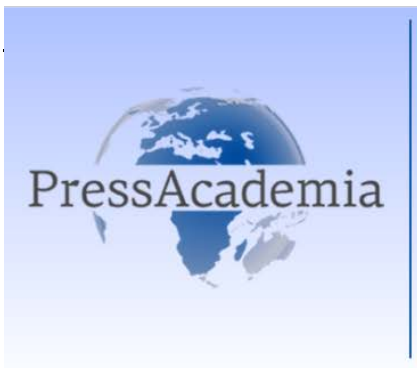

Press Academia Procedía

Global Business Research Congress (GBRC), May 26-27, 2016, Istanbul, Turkey.

\title{
LEAN PROCEDURES IN HOSPITAL AND MEDICAL SUPPLY CHAIN PROCESSES
}

\section{DOI: 10.17261/Pressacademia.2016118625}

\author{
Mustafa Isik', Fikriye Isik ${ }^{2}$ \\ 'Medicalpark Health Group. mustafa.isik@mlpcare.com \\ ${ }^{2}$ Dr.Lutfi Kırdar Training and Research Hospital. fikriye.isik@sbkeah.gov.tr
}

\begin{abstract}
Decreasing incremental medical costs and expenses, increasing quality, maximizing patient and employee satisfaction are all among principal objects of healthcare facilities. It is necessary revising and simplifying all processes in order to achieve those objectives. Lean thinking, among others, is the best way to this end along with lean principles. Lean thinking and lean principles are not only eliminating all activities, which do not add value to processes, but they also aim reducing time spared for value-added processes. A management philosophy which addresses all processes with the motto "there will be always a problem to resolve and a cost to eliminate" is the basic factor, which ensures development. Health managers and each stake holder with an actual role in healthcare service should identify wastage and inefficiencies in relevant area, if those managers and stakeholders have all processes down to a fine art. Achievement originates from possession of techniques, time and knowledge by concerning parties to resolve problems, along with the view of continuous improvement. This study aims to identify factors leading to wastage in Supply Chain Processes, which are among the most critical processes of hospitals, and applications, which will add value to those processes by increasing quality of those processes. In this end, it is to demonstrate applicability of the Lean Supply Process Model by addressing all activities with and without added-value at all stages, ranging from product request and requirement planning to delivery of products to main store, transfer from main store to substores and inventory count and invoicing.
\end{abstract}

Keywords: Lean hospital, wastage management, efficient use of resources, lean procedures in supply chain processes.

JEL Codes:: F50, H51

\section{HASTANE VE TIBBi TEDARIK ZINCIRI SÜREÇLERINDE YALIN UYGULAMALAR}

\section{ÖZET}

Sağlıkta artan maliyetleri ve israfı azaltmak, kaliteyi artırmak, hasta ve çalışan memnuniyetini en üst seviyeye yükseltmek sağlık hizmeti sunan kurumların erişmek istediği temel amaçlardandır. Bu amaçlara doğru yollarla ulaşmak için tüm süreçlerin gözden geçirilerek yalın bir hale getirilmesi gerekmektedir. Bu durumu sağlamanın en önemli yollarından biri de yalın düşünce ve ilkeleridir. Yalın düşünce ve ilkeleri, süreçlerde katma değer yaratmayan aktiviteleri yok ederken, katma değer yaratan işlemler için harcanan sürenin ise azaltılmasını sağlamayı amaçlamaktadır. Her zaman çözülmesi gereken bir sorun ve giderilmesi gereken bir israf vardır vizyonuyla süreçlere eğilen bir yönetim felsefesi, gelişmeyi sağlayan temel unsur olmaktadır. Hizmetlerinde mükemmele ulaşmayı hedefleyen sağlık yöneticilerinin ve sağlık hizmeti sunumunda görev alan her bir paydaşın görev aldığı alanla ilgili israfı ve verimsizlikleri görmesi önem arzetmektedir. İlgililerin bu sorunları çözecek tekniklere, zamana ve bilgiye sahip olması ile birlikte sürekli iyileştirme düşüncesi başarının yakalanmasını sağlayacaktır. Bu makalenin amacı; hastanelerin en kritik süreçlerinden olan Tedarik Zinciri Süreçlerinde israf kaynaklarının tespitinin yapılarak, bu süreçlerde kaliteyi artırmak suretiyle bu süreçlerde değer yaratacak olan uygulamaların neler olabileceğini ortaya koymaktır. Bu bağlamda; ürünlerin talebinin ve ihtiyaç planlamasının oluşumundan ürünlerin ana depoya teslim edilmesi, ana depodan tali depolara transfer edilmesinden hastaya çıkılması, stok sayımlarından ürünlerin faturalandırılmasına kadar geçen tüm aşamalarda katma değer yaratan ve yaratmayan aktiviteleri sorgulayarak Tedarik Süreçlerinde yalın modelin uygulanabilirliğini göstermektir.

Anahtar Kelimeler: Yalın hastane, israf yönetimi, kaynakların verimli kullanılması, tedarik zinciri süreçlerinde yalın uygulamalar JEL Kodları: F50, H51 


\section{GíRiş}

Yalın yaklaşım, hastanelerin organizasyonunu ve yönetim şeklini değiştirebilen, hastanelerin hatalarını, bekleme sürelerini azaltarak hasta bakım kalitesini arttırmalarına imkân sağlayan, çalışanları ve yönetimi destekleyerek hizmet akışındaki engelleri ortadan kaldıran ve hasta odaklı sağlık hizmeti sunmaya imkân sağlayan, malzeme ve stok yönetiminde israfı önleyerek şirkete katma değer sağlayan bir yaklaşımdır.

Sağlığa olan talep, yaşam süresinin uzaması ve teknolojik gelişmelerden dolayı artmakta ve bu durum beraberinde de sağlık giderlerinin de kontrolsüz şekilde artmasına neden olmaktadır. Sağlık harcamalarındaki enflasyon, ekonominin genel durumundaki artıştan daha fazla olarak karşımıza çıkmaktadır. Aynı zamanda hastanelerde birçok masrafın ve israfın gereksizce arttığı da görülmektedir. Bu artışlar birçok hastane ve sağlık sisteminde yalın prensiplerin uygulanmaya başlama gerekliliğini beraberinde getirmiştir. Yalın uygulama prensiplerinin sağlığa uyarlanmasıyla dikkat çekici sonuçların ortaya çıktığı görülmektedir. Yalın prensiplerin ana amacı her şeyi hastanın bakışından görmek, düşünmek ve yapmaktır. Hastayı sağlık sisteminin süreçlerini oluşturan değişik kademelerinden süratle geçirmek ve mümkün olan her yerde standartlaşmayı gerçekleştirmektir. Geçmişten gelen gelenekler ve tıbbi yaklaşımlardan ortaya çıkan birçok engele rağmen birçok hastane, gerek kalite ve gerekse sağıık harcamalarında önemli gelişmeler sağlamaktadır.

Yalınlık; kaynak kısıtlarının baş gösterdiği, maliyetlerin düşürülmesinin çok önemli olduğu pek çok alanda uygulanabilirliği olan yeni bir yönetim anlayışı olarak ortaya çıkmaktadır. Yalın yöntemlerin ana amacı, bir sistem içindeki tüm israfı ortadan kaldırmaktır. Klasik yönetim anlayışlarından radikal değişikliklerle farklılıklar gösteren yalın organizasyon öğeleri, israfı azaltmak isteyen organizasyonlara büyük kolaylıklar sağlamaktadır.

Sağlık sistemlerinde ekonomik açıdan etkili ve verimli olamama durumu sürekli olarak devam etmektedir. Bunun en büyük sebebi, sağlık sistemi aktörlerinin hemen hemen hiçbirinin ekonomik olmalarını teşvik edecek güdüleyicilerinin olmamasıdır. Sağlık sistemleri bir yandan daha bireysel sağlık bakım hizmet süreçleri sunup, diğer yandan performansı, verimliliği ve hasta tatminini artırma baskısını yaşamakta ve bu baskı giderek artmaktadır Bunun sebepleri arasında bütçeyi aşan maliyetler, hasta güvenliğini riske eden hatalar, hastaların boşa harcanan vakti ve genel bürokratik verimsizlikler sayılabilir. Yalın bakış açısıyla problem sağlık hizmetlerinde özellikle hastanelerde var olan israfın nasıl ortadan kaldırılacağıdır. Sağlık sektörü, bakımın kalite ve etkinliğini iyileştirmek ve giderleri azaltmak için yöntem ve teknikleri öğrenerek müthiş bir fırsata sahip olabilir; aynı zamanda insan kaynaklarını da bu çabaya ortak edebilir. Problemi "çok az verimlilik" yerine "çok fazla israf" şeklinde çerçevelemenin kavramsal ve işlemsel yararları vardır. "Verimlilik" çağrısı hasta memnuniyeti ve sosyal adalet taahhüdünü iletmede yetersizdir. İsraf kavramının finansal verimlilik uğruna memnuniyet ve sosyal adaleti ikinci plana itmesi, bu hareketin kusurlu bir yönüdür.

Ayrıca belirtilmesi gereken bir husus da israfın kemikleşmesi sorunudur. Bazı faaliyetlerin neden yapıldığı uzun süre sorgulanmadığında bu sorunla karşılaşmak muhtemeldir. Yapılması gereken şey, gerçekleştirilen tüm faaliyetler hakkında "neden" sorusunu tekrar tekrar sormaktır. Neden sorusunu tekrar etmek sorunun kök nedenlerine inmeyi sağlayacaktır ve altta yatan nedene daha kolay ulaşılacaktır. Ancak bu metotla bu sorunun üstesinden gelmek mümkündür. Örneğin stok kontrolü gibi destek fonksiyonlar genellikle israf olarak düşünülmez. Ancak stok kontrolü müşterilerin ürünlerini materyallere dönüştürmez. Örneğin bir stenti hastanın damarına yerleştirmez. Envanter kontrolünün kendisi; hastada görünür, hastaya değer katan bir faaliyet değildir ve dolayısıyla bu anlayışa göre israftır. İsrafı tanımlarken müşterinin bakış açısını almak anahtar noktadır. Yararlı çabalardan değer katanları ve değer katmayan israfları ayırmak önemlidir. (Şimşir í. 2013).

\section{LITERATÜR TARAMASI}

Sağlıkta artan maliyetleri ve israfı azaltmak, kaliteyi artırmak, hasta ve çalışan memnuniyetini artırmak Yalın Düşünce ve ilkeleriyle sağlanmaktadır. Çünkü yalın dönüşüm, katma değer yaratmayan aktiviteleri yok ederken, katma değer yaratan işlemler için harcanan sürenin ise azaltılmasını sağlar. Hastanelerde yalın yönetim; Hastane yatan hasta katlarında, poliklinik hizmet alanlarında, ameliyathanelerde, görüntüleme ünitelerinde ve laboratuvarlarda temel düzen ve istikrarı sağlamayı amaçlar. Aynı şekilde, teşhis ve tedaviyi kapsayan doğru klinik rotalarını tespit ederek başlangıçtan neticeye kadar paylaşılan değer akışları oluşturmak temel hedeflerdendir. Yalın üretimle sağlık hizmeti sunumunda, insan kaynaklarının etkin ve efektif kullanımı ile 
kaliteli sunumu ön plandadır. İş sürecinde sıfır hata sağlanarak kaynakların israf edilmesinin önüne geçilmeye çalışılmaktadır.

Hastaneler, diğer kuruluşlarla karşılaştırıldığında gerek yerleşim düzeni gerekse cihaz ve donanımlarda kullanılan teknoloji açısından daha karmaşık bir yapıya sahiptir. Teknoloji yönetimi bu nedenle büyük önem taşımaktadır. Hastanelerde yüksek risk taşıyan servisler başlıca acil servis, ameliyathane, yoğun bakım ve radyolojidir. Bu servislerde doktor ile hasta belirli bir prosedür için de kısa süreli beraber olmakta cihazlarda ileri teknoloji kullanılması nedeniyle cihaz arızaları ve kullanım hataları ile sık karşılaşılabilmektedir. Tıbbi personel açısından tecrübe ve zamanlama büyük önem taşımakta, çoğu kez çabuk karar verilmesini gerektirmektedir. Bundan dolayı sağlık işletmelerinde esneklik ve müşteri odaklı çalışma büyük önem taşımaktadır.

Yalın üretim sistemi sadece bir iş organizasyonu değildir. Sağlık hizmetinin sunulduğu hastane gibi mekânların inşaatı da yalın üretim sistemine göre gerçekleştirilmektedir. Araştırmalar göstermiştir ki, hasta akış süreci olarak tabir ettiğimiz sistemde hastanın daha az hareket etmesi, hizmetin kendisine getirilmesi, hizmet odaklı olunması yalın üretimle mümkün olmaktadır. Burada zaman ve enerji anlamında ciddi bir kazanımdan söz edebilmek mümkündür. Birçok yalın hastane uygulamasında hastane binalarının önceden tasarlanmış ve inşa edilmiş olmasından dolayı birçok kısıtla karşılaşılmaktadır. Hastanede çalışanların kendilerine başvuran hastalara en iyi hizmeti sunmaları ve sağlıklarını en iyi duruma getirmeleri gerekmektedir. Fabrikalarda inşaat tamamlandıktan sonra ortaya çıkan ihtiyaca göre makinaların yerlerinin değiştirmek mümkün olabilmektedir. Ancak hastaneler inşaat sırasında yalnız makro seviyede değil orta seviyedeki operasyonları da sabitlemektedir. $\mathrm{Bu}$ ortamda hastane faaliyete geçtikten sonra mekanları ve hizmet alanlarını değiştirmekte büyük sıkıntılar ve maliyetler olmaktadır. Ameliyat odalarının yerleri ve adetleri, hastaların yattıkları odalar ve bulundukları alanlar, hastaların teşhis ve tedavi sırasında diğer katlar ve binalar arasında nakilleri ve bekleme alanları önceden belirlenmektedir.

Bütün bu sebeplerden, yalın hastane prensiplerinin hastane binası tasarımı ve inşaatı sırasında uygulanmasını gerektirmektedir. Klasik hastane inşaatlarında hastanede çalışacak tıbbi personele ve hastaneden istifade edecek hastalara çok geç danışılmaktadır. Hastane inşaatındaki teknik spesifikasyonlar tıbbi uzmanlık ve cerrahi uygulamalar uzmanlık bölümlerine göre yapılmaktadır. Halbuki ana hasta akışlarına (poliklinikler, günlük vakalar, hasta teşhis, yatan hasta cerrahisi, uzun süreli tedaviler ve zihinsel hastalıkların tedavisi gibi) göre yerleştirme tasarımlarının yapılması gerekmektedir. Hastane tasarımlarını yapanlar değişik kaynaklardan aldıkları bilgileri sentezlemeye ve farklı görüşleri birleştirmeye çalışmamaktadırlar.

Hastane binası ve tesisinin tasarım ve inşasında yalın yaklaşım birçok yönden farklılık arz etmektedir. Hastane binasına yapılacak başvurunun (başvuracak hasta sayısı, yapılacak sağlık müdahaleleri, hedeflenen kalış süreleri, ameliyathanelerin kullanım hedefleri ve görüntüleme ekipmanının kullanım verimliliği) anlaşılmasından sonra başvuracak hastalara müştereken hizmet sunan değişik birimlerin personelini bir araya getirerek "hasta ana akış yolları" belirlenir. Hasta akış yolları belirlendikten sonra da hizmet birimleri tasarlanır ve yerleştirilir. Arkasından bina ve tesis tasarımı detaylandırılır. Hastalara her gün hizmet sunan doktor, hemşire ve teknisyenler bir araya getirilerek hastalara hizmetin sunuşu ile ilgili simülasyonlar yapılır ve acil başvurudan hasta yatışına kadar gerçek modeller tasarlanır. Binaların ve mekanların daha uygun ve verimli kullanımıyla hastane yönetim giderleri önemli ölçüde azalır. Hastaların ve personelin katılımları çok daha iyi tedavi sonuçlarını ve ilgilenen herkesin yüksek memnuniyetini sağlayacaktır. (Willats P., http://www.lean.org.tr/neden-yalin-hastanelerkurmaliyiz/. Yalın Enstitü, Türkiye).

Yalınlık, optimum hasta bakımı sağlanmasında maliyetleri kontrol ederken aynı zamanda kalite ve verimliliği de artırmaktadır. Yalınlığın altında yatan amaç, hasta için değer oluşturmaktır. Yapılan çalışmalara bakıldığında; sağlık hizmetlerinde yalın düşünce çoğunlukla bir süreç iyileştirme yaklaşımı olarak kullanılmaktadır ve üç ana alan üzerine odaklanmıştır: hasta açısından değeri tanımlamak, değer akışlarını haritalamak ve sürekli akışı oluşturmak için israfı ortadan kaldırmaktır. Değer akışı haritalama sağlık hizmetlerinde en sık uygulanan yalın bir araçtır. Her zamanki uygulama adımları, yalın eğitimin verilmesi, pilot projelerin yapılması ve disiplinler arası ekipler kurarak iyileştirmelerin yapılmasıdır. Yalın girişimlerin sonuçları iki alana odaklanmaktadır. Birincisi sağlık kuruluşlarının performansını, ikinci ise sağlık çalışanlarının çalışma ortamının geliştirilmesini ön plana çıkarmıştır. Sağlık kuruluşlarının performansının iyileştirilmesi, hasta bakımı sayısında artış sağlamıştır ve hastaların bekleme sürelerini azaltmıştır. Sağlık çalışanlarının çalışma ortamının geliştirilmesi ise; sağlık bakım 
süreçlerinin iyileştirilmesi ve sağıı çalışanlarının rolünün daha aktif olmasını sağlamaktadır. Ayrıca daha öngörülebilir ve sakin çalışma ortamı sunmaktadır. (Yıldız, S., Yalman F., 2015).

Günümüzde, işletmelerin hızla değişen koşullara uyum esnekliği kazanarak belirsizliklerden kaynaklanan krizleri yönetebilmeleri, varlıklarını sürdürebilmeleri için yalın ilkelerin uygulanması temel şarttır. Yeni koşullara uyum sağlamak isteyen işletmeler, üretim ve hizmet yapılarını bu doğrultuda yeniden yapılandırmak amacıyla yalın dönüşüm çalışmaları yapmışlardır. Son zamanlarda yalın sağlık, küresel bir hareket olmaya başlamıştır. Bunun nedenleri, bütçeyi aşan maliyetler, hasta güvenliğini riske eden hatalar, hastaların boşa harcanan vakti ve genel bürokratik verimsizliklerdir. Yalın bakış açısıyla, problem, israfın nasıl ortadan kaldırılacağıdır. Hizmet üreten işletmelerden olan sağlık işletmeleri de giderek gelişmektedir. Toplum giderek yaşlanmakta ve bundan dolayı sağlık hizmetlerine olan talep giderek artmaktadır. Ancak sağlık sistemlerindeki finansal koşullar gerektiği kadar iyi şekilde ve hızda iyileştirilememektedir. Ancak son zamanlarda hasta memnuniyet düzeyinin ve beklentilerinin artmasından dolayı, sağıı hizmetlerinin mümkün olduğunca, uygun fiyatlı, erişilebilir, güvenli, düzenli, verimli ve maliyet etkin olması için daha fazla çaba harcanması gerekmektedir. Sağık hizmetlerinin finansmanını ve hasta bakımını geliştirmek için, yeni ve daha verimli yollar aranmaya ihtiyaç vardır. Birçok sağlık kuruluşu, performans iyileştirme yaklaşımı olarak Toyota Üretim Sistemini kabul etmiştir ve genellikle Yalın Sağlık Yönetim Sistemi olarak adlandırmıştır. Yalın yaklaşım bir kuruluşun mevcut süreçleri çerçevesinde iyileştirmeler sağlamaktadır. Yalın üretim, büyük ölçekli yatırımları ve yeniden kurumsallaşmayı gerektirmeksizin; sağlık kuruluşlarına, yüksek yatırımlar yapmadan iyileştirmeleri başarmak için alternatif bir yöntem sunar. Yalınlık, sağıı kuruluşlarında başarılı olduğu kanıtlanmış olan yenilikçi bir yönetim yaklaşımıdır. (Yıldız, S., Yalman F., 2015).

\section{VERI VE YÖNTEM}

Hastane ve tıbbi tedarik zinciri süreçlerinde yalın yönetim ve verimlilik uygulamaları ile ilgili literatür taraması yapılarak tanımlayıcı tipte bir araştırma yapılmıştır. Herhangi bir anket ya da görüşme yöntemi kullanılmamış olup, gözlem ve derleme yoluyla çalışma tamamlanmıştır.

\section{BULGULAR VE TARTIŞMA}

\subsection{Sağlık Hizmetleri Sunumunda Yalın Uygulamaların Önemi}

Sağlık sektörü açısından tedarik zinciri yönetimi; malzemenin üretiminden hastaya ulaşana kadar geçen iş süreçlerinin uyum içinde hareketini sağlamak için ürünlerin ve bilginin akışını yöneten bütünleşik bir sistem olarak tanımlanmaktadır. (Tengilimoğlu \& Yiğit, 2013: 25).

Bilgi ve iletişim teknolojilerindeki ilerlemeler ve yeni yönetim anlayışındaki gelişmeler tedarik zincirini günümüzde daha da önemli bir konuma getirmiştir. Sürekli artan ve değişiklik gösteren rekabet koşulları işletmelerin tedarik zinciri içerinde yer alan faaliyetleri tek başlarına yapmalarını ve bu faaliyetlerde uzmanlaşmalarını imkansız kılmaktadır (Timur, 2013: 10). Hastanelerde tedarik sistemi; sağlıklı stok yönetimini, düzenli malzeme tedarikini, bakım ve hizmet sürecinin hızını ve kalitesini belirlemektedir. Tedarik sürecindeki değer katmayan tüm faaliyetlerin, hareketlerin ve süreçlerin ortadan kaldırılması, hataların en aza indirilmesi, hastanenin girdileri ile çıktıları arasındaki sürecin verimliliğinin artırılması ise, tedarik zinciri yönetiminde yalın ilkelerin uygulanması ile mümkün olabilmektedir.

Hastane giderleri içerisinde Tedarik Zincirine ilişkin giderler personel ve hekim giderlerinden sonra en yüksek paya sahip giderler olarak karşımıza çıkmaktadır. Hastanelerde toplam gelirler üzerinden bakıldığında \%40 lar civarında bir oran satınalma alımlarını oluşturmaktadır. Bu denli büyük oranda paya sahip olan bir süreç bütününde tüm uygulamaların detaylıca analiz edilmesi ve israf kaynaklarının tespit edilerek doğru süreçlerin kurulması gerekmektedir. Zincirin her aşamasında sistem içerisindeki kaynakların boşa harcanmasına neden olan ve değer yaratmayan faaliyetlerin ortadan kaldırılması amacıyla işletme süreçlerinin yeniden yapılandırılması gerektiğini savunan yalın tedarik zinciri, işletmenin tüm fonksiyonlarının bütünleştirilmesini sağlar. Bu sayede yüksek kullanım oranı, daha kısa teslim süreleri ve toplam tedarik zinciri maliyetlerinin en aza indirilmesi sağlanabilir. 
Tedarik zinciri yönetiminin temel amacl, müşteri tatminini düşürmeden ürünlerin istenilen zamanda, doğru yerde ve istenilen miktarda bulunmasını sağlamak, maliyetleri azaltmak, rekabet avantajı elde edebilmek ve tedarik zinciri sürecinde ürünlerin katma değerini artırabilmek için stratejik bir güç oluşturmaktır. Tedarik zinciri yönetiminin ayrıca kaynakların verimliliğinin artırılması, stok dönme hızında artış, gelirlerde artış, tedarik zinciri yönetimi maliyetlerinde azalma, ürün bulunabilirliği, sipariş karşılama süresinin azalması, ekonomik katma değer yaratılması, talebe cevap verme ve talebi karşılama yeteneğinde gelişme, bilgi aktarımı, sermayeden yararlanma, pazara ulaşım süresinde azalma, lojistik maliyetlerden tasarruf sağlama, müşteri tatminini artırma, çevrim zamanını kısaltma ve ürün hatalarını azaltma, zaman israfından kaçınma, pazarda rekabet edebilme gücünün artması, daha yeni teknolojiye sahip olma gibi amaçları da bulunmaktadır. (Timur \& Başkol, 2013).

Hastanelerde tedarik sistemi; sağlıklı stok yönetimini ve düzenli malzeme tedarikini sağlayıp, bakım ve hizmet sürecinin hızını ve kalitesini etkilemektedir. (Tütüncü \& Küçükusta, 2008: 31). Yalın tedarik zinciri kavramı ise; maliyet, kalite ve verimlilik kavramları üzerinde önemli etkileri olması, süreçlerdeki hata ve israfın azaltılması gibi özellikleri nedeniyle sağ ık sektöründe de uygulanabilecek önemli bir yaklaşım olarak karşımıza çıkmaktadır. Sağlık sektöründe yalınlık, değer katmayan tüm faaliyetlerin, hareketlerin ve süreçlerin ortadan kaldırılması, hataların en aza indirilmesi, hastanenin girdileri ile çıktıları arasındaki sürecin verimliliğinin artırıması anlamına gelmektedir. (Graban, 2011: 53).

Yalın düşünce, sadece sağlık sektörü ile ilişkili olmayıp; israf, zaman, para, tedarik, ürün ve hizmetin olduğu her yerde kullanılabilecek bir düşünce sistemidir. Sağlık kuruluşları da dâhil olmak üzere, tüm kuruluşlar, bir dizi süreç, faaliyet ve kendisine bağlı olanlara sunmakla yükümlü olduğu değerlerden oluşmaktadır. Bu değerlerini maksimize ederek israfları ortadan kaldırmak için sağlık aktörleri, diğer örgütlerde olduğu gibi, kullanıcılar tarafından istenen değerleri belirlemek, katma değeri olmayan adımları ortadan kaldırmak ve tüm bunları yaparken değer akışının başından sonuna kadar hastaların ihtiyaçlarına göre hareket etmek zorundadırlar.

Sağlık sektörüne özgü tedarik zinciri üyeleri; üreticiler, kamu ve özel sağlık kuruluşları (hastaneler, ağız ve diş sağlığı merkezleri, aile sağlığı merkezleri vb.), eczaneler, özel hekim muayenehaneleri gibi sağlık hizmeti sunan ve finanse eden kuruluşlar, sigorta şirketleri ve ekonomik yapıları düzenleyici kurumlar ve hastalardır. Sağlık sektörü için tedarik zincirinin önemli üyelerinden biri olan üreticiler, ilaç ve farmasötik üreticileri; tıbbi ve cerrahi araç ve aparatlar, protezler, röntgen cihazları, elektroterapi ekipmanları gibi tıbbi cihaz üreticileri; bilgi sistemleri üreticileri ve şırınga, ameliyat bıçakları, kan ve örnek alma kitleri, hastane laboratuvar ürünleri, yara bakım üniteleri ve damar içerisine yerleştirilen stentler gibi medikal ve cerrahi malzeme üreticileri olarak belirtilebilir. (Özkan, O. 2015)

Yalın tedarik zinciri uygulamaları doğru yapıldığında, çalışanlara uzun vadeli bakış açısı kazandıran bir yol haritası sunabilir. Yalın hale gelmenin amaç ve yararlarını net biçimde iletişime açar. Şirketin şimdiki halinden, arzu edilen durumuna nasıl gelebileceğini haritalandırır. Ve her büyük değişim yönetimi girişiminde olduğu gibi, yalınlığın yol haritası da tepe yönetim için olmazsa olmaz bir destek unsurudur. Şirketin, organizasyondaki çalışanlara yönelik bakış açısı da başarılı kültürel değişim için kritik öneme sahiptir. (http://www.dergil.com/tr/dergi/nisan-mayis-2007/yatay-entegre-is-modeli-olarak-yalin-tedarik-zinciri yonetimi/177.aspx)

Yalın tedarik zinciri, değer katmayan ya da başka bir ifadeyle israflardan arınmış, sadece değeri tasarlayıp, üreten ve müşterisine taşıyan bütünleşik aktivitelerden müteşekkil işlerin ağıdır. Tedarik zincirini, bir zincir olarak değil, "ağ" olarak tanımlamak daha doğru olacaktır. Zira artık günümüzde Tedarik Zinciri Yönetimi, bir çok ayrı ayrı tedarik zincirinin birbirlerine eklemlendiği kompleks tedarik zinciri "ağ"ı üzerinden yapılıyor. Sadece kendi tedarik zincirimizi yönettiğimiz konforlu alandan çıkıp, tedarikçilerimizin ve müşterilerimizin tedarik zincirlerini de yönettiğimiz büyük resme bakıyoruz artık. Bu büyük resimden, çıkarma sanatı ile israfların ayıklanması bizi yalın tedarik zincirine götürecektir. http://www.satinalmadergisi.com/2014/07/04/tedarikzinciriniz-yalin-mi/ Erişim Tarihi : 11.08.2015)

\subsection{Tıbbi Tedarik Zinciri Satınalma Süreçlerinde Yalın Uygulamalar}

Yalın tanımı ile firmanın sunduğu ürün veya hizmetin oluşturulması için gerekli olan girdilerin sağlanmasını amaçlayan satın alma fonksiyonu, tedarik zincirlerinde daha farklı ve önemli bir role sahiptir. Tedarik edilen maddelerin daha önceden belirlenmiş bir plana göre belirli yerlerde bulundurulmalarının gerekliliği, dünyanın 
değişik yerlerine yayılmış tedarik noktaları ve daimi bir şekilde daha düşük maliyete duyulan ihtiyaç tedarik zincirlerine bağıı satın almayı, önemi yüksek bir tedarik zinciri fonksiyonu haline kısa sürede getirmiştir.

Başarılı bir satın alma yönetimi için sadece maliyet değil, stratejik satın alma planlama, stok kontrolü, tedarikçi yönetimi, satın alınan ürünün lojistiği, satın alma işlemlerinin planlanması ve yönetilmesi gerekliliği günümüz tedarik zincirlerinin satın almadan beklentilerini değiştirmiştir. Uluslararası ticaretin kolaylaşması ile satın alma departmanları daha önce ulaşamadıkları birçok tedarik noktasına ulaşma şansı bulmuşlardır. Tedarik zincirlerinin artan derecede karmaşıklaşması, satın almada da değişikleri beraberinde getirmiştir. Günümüz tedarik zincirlerinde satın alma departmanları ve fonksiyonları ancak firmanın tüm birimleri ile entegre edildiğinde satın almadan beklenen faydalar sağlanabilmektedir.

Yalın satın alma; hatasız, fazlalıklardan kurtularak, en kaliteliye, en hızlı bir şekilde, optimum stoğu hedefleyerek ulaşma şeklinde açıklanabilir. Ürün çeşitliliğinin ve üretim kapasitelerinin arttığı bir pazarda satın alma ve tedarik fonksiyonlarının stratejik karar vermedeki etkisi gün geçtikçe artmaktadır. Firmalarda satın alma maliyetlerinin toplam maliyetlerinin \%60-\%70 lere ulaştığı bir ortamda satın alma önemli bir fonksiyon olarak karşımıza çıkmaktadır. Satın alma sadece maliyetleri düşüren değil ama aynı zamanda değer arttıran bir olgudur. Yeni ürünlerin daha hızı bir biçimde piyasaya çıkması entegre yönetim ekiplerini zorunlu kılmaktadır. Entegre yönetim takımı adı verebileceğimiz bu ekip firma içindeki bütün birimlerden oluşmalı ve yönetimde fonksiyonel yaklaşım değil süreç yaklaşımı benimsenmelidir. Malzeme ve bilgi akışlarını entegre eden bütüncül bir yaklaşıma doğru genel bir trend vardır. Böylelikle malzeme ve bilgi akışı firma bünyesinde ve firma dışında İşletme Kaynak Planlaması ve Tedarik Zincir Yönetimi gibi metotlarla birbirine bağlanmalıdır. Satın alma sürecine tedarikçilerin katılımının "maliyetleri" düşürdüğü artık kabul edilen bir gerçektir. Bu nedenle firmalarda kendilerine uygun "Firma-Tedarikçi" etkileşimini oluşturmak zorundadır. Tedarikin stratejik maliyeti kısa vadeli fiyatından daha da önemli hale gelmektedir.

Etkin bir satın alma stratejisinin belirlenmesi için firma düzeyindeki tüm yöneticilerin satın alma prosesini bir bütün olarak algılaması gerekmektedir. Bu strateji geliştirilirken firmanın var olan organizasyon yapısı, firma içi iletişim sisteminin düzeyi, firmanın ve yöneticilerinin geçmiş tecrübeleri, var olan kaynaklar ve firmanın sahip olduğu kültür dikkate alınmalıdır.

Önemli tedarikçilerin firmanın satın alma departmanları ile beraber çalışıp, tedarikten kaynaklanan veya kaynaklanabilecek sorunların çözümlerine katkıda bulunduğu bir yapının yalın bir şekilde oluşturulması hedeflenmelidir. Merkezi bir birim haline gelen satın alma organizasyonu, hizmet planlama ile beraber çalışan çapraz fonksiyonel çalışma birimlerinden oluşur. Firmayı oluşturan değişik bölümlerin satın alma fonksiyonları bir araya gelerek satın alma işlemlerini tek bir merkezden yönetmeye başlarlar. Bu nedenle satınalmacıların geniş ticari bilgiye sahip, yüksek eğitimli, takım çalışmasına yatkın, ileri düzeyde iletişim yeteneğine sahip, şirketin uzun dönem stratejisini anlayıp uygulayabilecek kişiler arasından seçilmesi gerekmektedir.

Bir firma tedarikçileri ile vardır. Müşteriler zaten vardır. Doğru ürünü uygun fiyata bulduklarında her zaman sizinledir. Tedarikçiler de bu böyle değil. Yükümüzü alan, alnımızın akıyla iş yapmamızda önemli yere sahip oldukları unutulmamalıdır. (http://www.dergil.com/tr/dergi/kasim-aralik-2011/tedarik-zincirinin-sifir-noktasisatin-alma/414.aspx erişim tarihi; 28.08.2015).

\subsection{Stok Yönetimi Süreçlerinde Yalın Uygulamalar}

İşlerimizi yapmak için gerekli olandan daha fazla stoka sahip olmamız anlamına gelen stok, israf yani değersiz olarak tanımlayacağımız stoktur. Stoklar çok fazla olduğunda hastanenin nakit parası raflarda duran stoğa bağlanır ya da malzeme ve ilaç ürünlerinin miadı dolarak fireye çıkmasına neden olarak mali kayba neden olacaktır. Yalın stok yönetiminde amaç düşük stok tutmak demek değildir. Bu şekilde yanlışlığa düşen bir çok şirket kendisini ciddi zarar vermektedir. Yalın stok yaklaşımında amaç, hasta ihtiyaçlarını dikkate alarak bu ihtiyaçlar doğrultusunda optimum stok hesabının yapılarak planlamanın yapılmasıdır. Stok tutmaya neden olan sebeplerin tespit edilerek bu sebeplerin ortadan kaldırılması hedeflenmelidir. Fazla stok tutma sebebi ilgili departmanların ürünlere istediği anda ulaşmayacağını düşünerek güven duymamasından mı kaynaklanmakta ya da hasta ihtiyaçlarının doğru tespit edilememesinden mi kaynaklandığı doğru analiz edilmelidir. Bu nokta iç müşterinin güvenini oluşturabilmek için dış müşteri olan tedarikçilerin ürünleri istenilen zamanda tedarik 
edebilmeleri büyük önem arz edecektir. Ürün teslimine güvenilmeyen tedarikçilerle çalışıması durumunda ürün yokluğunu yaşatma riski de aratacak ve bu durumda güvensizliğin temel nedenini oluşturacaktır.

Gereğinden fazla stok bulundurmanın hem alan hem de nakit israfına yol açacağı bilinciyle hareket edilmesi gerekmektedir. Hastanedeki her bir metrekarenin hizmet üretebilip, gelir getiren birimlere ayrılması gerekirken bu alanları fazla stoktan dolayı depo olarak konumlandırılması hem gelir kaybına hem de gereksiz bulundurmaktan dolayı nakit kaybına yol açarak şirketi 2 noktadan da kayba uğratacaktır. Tam tersi olarak düşündüğümüzde gereği kadar stok tutulmaması da ek hareket, maliyet ve acil siparişlerden dolayı sevkiyat ve sipariş israfına neden olacaktır. Çalışanlar depolara plansız ek yürüyüşler yapmak zorunda kalacak ya da satıcılara acil siparişler vererek daha pahalı alımlar gerçekleşecektir. Yalın stok yönetimi ortamında doğru malzemelerin ve stoğunun tutulması doğru hasta bakımı sunmaya yardımcı olurken, hastane açısından da maliyetlerin ve israfın azalmasını sağlar.

Yalın uygulama felsefesinin gereksiz insan hareketini minimuma indirmeyi hedeflediğini düşündüğümüzde malzeme yönetimi açısından ameliyathanelerde her bir ameliyat için ameliyat paketlerinin oluşturulması ameliyat hemşiresinin her ihtiyaç duyulan ek malzeme için depoya gitmesini engelleyecek ve azalan hareket israfı kişinin işgücü kaybını da engelleyecektir. Aynı şekilde hasta katında hasta odalarına tedavi için hemşirelerin her bir malzeme için hemşire ofisine dönüp gelmesi arzulanan bir durum değildir. Yapılan bir çalışmada Bir hemşirenin 12 saatlik bir nöbette 6-7 kilometre yürüdüğünü gösterdiğini düşündüğümüzde bu hareket israfının önlenmesinin gerekliliği daha çok önem kazanacaktır.

Fazla stokların bir çok problemi sakladığı düşüncesiyle hareket ederek stok yapısında yalın bir modelin kurulması gerekmektedir. Stok devir hızı arttıkça yalın stok yönetiminin arttığı düşünüldüğünde hedeflenen noktanın optimum stok tutma noktası olmasıdır. Yapılan üretim fazlalıkları, yanlış hesaplanan ihtiyaçlar, zamanında gerçekleşmeyen siparişler, tasarım yanlışııkları stok artışını tetikleyen temel unsurlardır. Dolayısı ile iş işten geçtikten sonra problemin kaynağına inmek yerine kriz yönetimi kurularak sorunun üzerine gidilmesi gerekir. Buda problemin kaynağına inilmemesi anlamına gelir.

\subsection{Tıbbi Tedarik Zinciri Süreçlerinde Verimlilik ve Maliyet Analizi Çalışmalarında Yalın Uygulamalar}

Satın alma yöneticisi, daha düşük fiyatlarla satın alma amacına yönelik bir satın alma organizasyonunu yönetir. En düşük maliyete ulaşma gerekliliği, satın almayı üretim fonksiyonlarından bağımsız hale getirir. Satın alma, fabrika yönetimine bağlı olarak ayrı bir bölüm halinde çalışır. Satın almacılar genel yaklaşımlar yerine değişik alanlarda, örneğin bir ürün grubu gibi, en iyi fiyata ulaşmak için pazarlık eden aracılar olarak alanlarında uzmanlaşırlar. Satın alma organizasyonun kültürü, en düşük fiyata ulaşmak için tedarikçilerle sıkı pazarlıkları destekler. Satınalmanın performansı, fiyata ve tedarikçilerin dağıtım performanslarına bağlıdır.

Hastanede malzeme ve bütçe yönetimi açısından verimli bir yapının kurulabilmesi için en önemli gider kalemlerinden biri olan illaç ve malzeme maliyetlerindeki israfın da kontrol altına alınması gerekmektedir. Gereksiz yere hatayla açılan ve sterilliği bozulan bir malzemenin maliyeti, son kullanma tarihi geçmiş bir ilaç ya da malzemenin maliyeti, ameliyathane de kullanılmadığı halde atıklara atılan onlarca malzemenin maliyeti, amacına uygun olmayan şekilde kullanılan malzemelerin maliyetleri toplandığında hastanelerde çok ciddi yekünler oluşturduğu görülecektir. Bu durumların doğru ölçülebilmesi için her bir branşın gelir merkezi olarak gelirlerinin ölçüldüğü gibi gider merkezi olarak da kabul edilip giderlerinin de ölçülmesi gerekmektedir. Genel bir karlılık bakış açısıyla bakmak yanıltıcı olacaktır. Dolayısıyla her bir gelir merkezinin karlıık hesaplamaları yapılarak ve bu hesaplamalar için de önemli bir paya sahip olan ilaç ve malzeme maliyetleri ayrıntılı olarak analiz edilerek sonuçlar muhatapları ile paylaşılmalıdır. Aynı nitelikteki bir vakanın 2 farklı hekim tarafından çok faklı maliyetlerle gerçekleştirilmesi analiz edilmeli ve hatalı bir yaklaşım söz konusu ise düzeltme yoluna gidilmelidir. Tedavi hizmetlerini uygulayan profesyonellerin kendi koymuş oldukları standartları ve klinik yolları kendilerinin uygulamaması sonucu oluşan verimsizlikler ortaya çıkarılmalı ve israf kaynakları engellenmelidir.

Hastanın ilacının uygulanması sürecini incelediğimizde sürecin bir çok kontrol adımı vardır. Başlangıçta eczacılar doğru dozaj ve etkileşim kontrolünü yaparlar, akabinde eczane teknisyenlerinin yapmış oldukları çift kontrolden geçer ve uygulayacak olan hemşire doğru hastaya doğru ilaç verildiğinden emin olmak için kontrol yapar. Yalın 
bakış açısıyla bakıldığında bu kontrollerin hepsi aslında birer zorunlu israftır. Bu kontroller mevcut süreç mükemmel olmadığından ve hataya açık olmasından gereklidir. Yalın düşüncede esas hatalar gerçekleştikten sonra bulmak ya da çifte kontroller yapmaktansa daima süreci sorgulayarak hataların gerçekleşmesini önlemenin yollarını bulmaktır. Hatasızlaşma \%100 sağlanana kadar bu kontroller zorunlu israf olarak yapılmaya devam edecektir.

Laboratuvar test istem talepleri incelemeye alındığında aslında bir çok istenilen testin hazır paneller oluşmasından dolayı istenildiği ve gereksiz bir çok testin bu paneller nedeniyle istenildiği karşımıza çıkacaktır. Test panellerinin düzenlenmesi, 1 hafta içerisinde aynı protokolde aynı testin istenmesi durumunda hekimin karşısına uyarı bilgisinin çıkması, el alışkanlığı ile istenilen testlerin ayrı bir istem sekmesine alınması ve test istemleriyle ilgili kliniklerin belirli aralıklarla raporlarla bilgilendirilmesi neticesinde gereksiz test israfından $\% 5$ ila \%7 arasında tasarrufun sağlandığı görülmektedir.

\subsection{Tıbbi Tedarik Zinciri Süreçleri Organizasyon Yapısının Kurulmasında Yalın Uygulamalar}

Tedarik Zinciri Yönetimi süreçlerinin ayrıntılarına inildiğinde birden fazla iş tanımının bütünleşmesinden oluştuğunu görülmektedir. Satınalma faaliyetleri, Depoculuk faaliyetleri, Nakliye süreçleri, Stoklama işlemleri, Numune deneme aşamaları, Finansal fatura kabulleri, Lojistik süreçleri, ürünlerin çıkışının yapılması, Bütçe çalışmaları ve faturalandırma aşamalarının bağımsız olarak planlanması ve farklı kişiler tarafından sunulması değerler sürecinde boşlukların oluşmasına neden olacaktır. Bu nedenle bu süreçlerde yer alan çalışanların sürecin tümüne hakim olmaları israfın önlenmesi açısından büyük önem arz edecektir. Bu departmanların yöneticilerinin de kesinlikle tek çatı altında toplanması gerekmektedir. Tüm tedarik zinciri süreçlerini bilinmesi ve bütünlük içerisinde durum değerlendirilmesinin yapılması süreçleri yalınlaştırmakta ve iş tanımları arasındaki boşlukları da ortadan kaldırmaktadır. Bu nedenle Tedarik Zinciri Organizasyonunun kurulması ve işletilmesinde departmandaki tüm çalışanların tüm süreçleri öğrenip uygulayabileceği bir çalışma ortamının sunulması gerekmektedir.

Merkezi bir satın alma departmanının firma çapında ortak satın alma süreç ve politikaları uygulamayı amaçladığı bir ortamda satın alma birimleri arasındaki koordinasyonu sağlayarak, geniş çaplı satın alma kontratlarının tüm firma tarafından kullanılmasını sağlamak esas alınmalıdır. Satın almada bürokratik uygulamaların oluşmasına neden olmasına rağmen satın alma stratejisi ilk olarak bu aşamada görülür. Satın almanın ilgilendiği değişkenler, fiyat ve maliyete ilave olarak tedarik edilen ürünün kalitesini de kapsamaya başlar. Satın alma fonksiyonu sadece üretimi desteklemek yerine firmanın diğer satın alma işlemlerini de yerine getirir.

Üst yönetimin satın almaya olan ilgisinin arttığı bu aşamada, firmanın diğer fonksiyonları satın almanın değerini henüz fark etmemiştir. Tedarikçi yönetiminin, ana hedefi oluşturduğu bu seviyede satın alma tedarikçi portföyünü yönetmeye başlar. Satın alma organizasyonu, değişik bölümler arasındaki koordinasyonu ve iletişimi arttırmayı hedefler. Satın almacılar bu alanlarda tecrübeli kişiler arasından seçilerek analitik, toplam kalite yönetimi ve iletişim alanında eğitim alırlar.

\section{SONUÇ}

Sağlık hizmetlerinde yalın üretimin çoğunlukla bir süreç iyileştirme yaklaşımı olarak kullanılmakta ve üç ana alan üzerinde odaklanmaktadır. Bunlar, hasta ve kurum açısından değeri tanımlamak, değer akışlarını haritalamak ve sürekli akışı oluşturmak için israfı ortadan kaldırmaktır.

Klinik süreçlerde yalın uygulamalar; hasta bakım süreçlerinde, tıbbi personelin tedavi uygulamalarında, operasyon süreçlerinde, görüntüleme hizmetleri gibi alanlarda uygulanabilmektedir. Tedavi süreçlerinde kullanılan aletlerin, ekipman ve malzemelerin fonksiyonlarına göre stoklanması, her bir süreçten sonra kontrol listelerinin oluşturulması, hem hasta güvenliğini sağlayacak hem de tıbbi personelin hata yapma olasılığını minimize edecektir. Ürün erişilebilirliğini sağlayarak ve depolama alanını minimize ederek, hasta bakım alanlarını artırabilmek mümkün olabilmektedir. Sağlık kurumlarında farklı meslek gruplarının fonksiyonları arasında yüksek düzeyde koordinasyon gerekmektedir. Yalın uygulamalar ile hekimlerin tanı, tedavi hizmetleri, hemşirelerin bakım hizmetleri, eczacıların ilaç hizmetleri, sağlık teknisyenlerinin teşhis hizmetleri arasındaki koordinasyon kolaylaştıracak şekilde konumlandırılabilmektedir. Tedarik zincirinin başarılı olmasında tıbbi 
personelin görüşlerinin alınması da önem taşımaktadır. Özellikle alternatifi olan malzemelerin alım kararı aşamasında fayda/maliyetin belirlenmesinde tıbbi personelin görüşünün alınmasına özen gösterilmelidir. (Özkan, O. 2015)

Yönetsel süreçlerde yalın uygulamalar; yönetsel karar verme süreçlerinde, satın alma uygulamalarında, karar destek sistemlerinde, stok yönetiminde gerçekleştirilebilmektedir. Yalın uygulamalar kapsamında, hastanenin ihtiyaç duyduğu malzemelerin nasıl, ne kadar, ne zaman ve hangi şekilde temin edileceğini gösteren bir yol haritasının oluşturulması, hastanenin kaynaklarını daha verimli bir şekilde kullanmasına ve yönetsel kararların daha etkili bir şekilde alınmasına yardımcı olabilmektedir. Hastanelerde tedarik zincirinin yönetim fonksiyonu genellikle satın alma birimi tarafından yapılmaktadır. Hastanenin bir önceki yıla ilişkin satın alma kayıtlarının incelenmesi ile konsolide edilebilecek malzemeler ortaya çıkarılıp, satın alma sıklıklarına göre daha az tedarikçiye gereksinim duyulabilecek bir tedarik zinciri yönetimi modeli oluşturulabilmektedir. İlaç ve tıbbi malzeme giderlerinin sağlık harcamaları bütçe içinde önemli bir ağırlığı bulunmaktadır. Depolanan tıbbi malzeme ve ilaçlar sağlık kurumlarının toplam varlıklarının önemli bir bölümü oluşturduğundan; stok miktarının azaltılması yatırımın karlılığını yükseltmekte; dolayısıyla kurumun finansal pazardaki konumu güçlenmektedir. Bu açıdan hastanelerde stok yönetiminin etkin bir şekilde işlemesine özen gösterilmesi gerekir. Etkin ve verimli işleyen bir tedarik zinciri yönetiminin kurulmasının önemli miktarda altyapı ve yazılım yatırımı da gerektirmektedir. Tedarik zinciri yönetiminde yapılacak çok küçük bir iyileştirme bile hastanelere önemli kazançlar sağlayabilecektir.

Sağlık kurumlarında tedarik zinciri, tıbbi malzemelerin üretiminden hastalara ulaşmasına kadar olan tüm süreçleri kapsamaktadır. Günümüzde, değişen ve karmaşık çevre koşulları altında rekabet eden sağlık kurumlarının tüm bu süreçleri daha etkili, daha ucuz ve daha kaliteli bir şekilde gerçekleştirmeleri gereklilik haline gelmiştir. Sektörde, tüm süreçlerde israfın azaltılması, katma değeri olmayan faaliyetlerin elimine edilmesi ve tüm sürecin uyum içinde hareketinin sağlanmasına yönelik yaklaşımlar yer bulmaya başlamıştır. Bu çalışmada sağlık kurumlarının tedarik yönetimi süreçlerinde yalın düşünce yaklaşımının uygulanabilirliğinden ve olumlu etkilerinden bahsedilmektedir. Sağlık kurumlarında üretilen ve sunulan hizmetler insan hayatı ile ilgili olduğundan; süreçlerde meydana gelen herhangi bir aksaklık, telafisi mümkün olmayan sonuçlar doğurabilmektedir. Süreçlere katma değer katarak ve israfı engelleyerek verimliliği artırmak; yalın uygulamalar ile mümkün olabilmekte ve "güvenlik", "maliyet etkililik", "kalite”, "etkinlik", "karlılık", "inovasyon" ve "iş yaşamı kalitesi" gibi sağıı kurumlarının yanı sıra her işletme için önemli kavramlar üzerinde önemli değişimler yaratılabilmektedir. Yalın tedarik zinciri yönetimi, sağlık kurumlarının mevcut süreçlerini doğru bir biçimde tanımlayarak; güçlendirilmiş, verimli, eksiklikleri tanımlayıcı ve israfı ortadan kaldırıcı süreçler ortaya konulmasına yardımcı olmaktadır.

Sadece yönetsel ve klinik süreçler olarak yalın yönetime bakılması yeterli olmayacaktır. Mimari süreçlerin ve dolayısıyla inşai faaliyelerde de yalın yönetim uygulamalarının planlanması daha sonra karşılaşılacak olan engellerin zamanında aşılmasını sağlayacaktır. Hastane binası ve tesis tasarımının odağına, hasta ihtiyaçlarını odak noktası alan yalın düşünceyi uygulamak temel hedef olmalıdır. Yalın yöntemle yapılmamış klasik yöntemle inşa edilen hastaneler ve hizmet binaları uygulayıcılar tarafından reddedilmekte ve bu sebepten de birçok israf ve birçok mutsuzluk, sıkıntı yaşanmaktadır. Yeni hastane binası inşa ederken yalın prensipleri uygulamak suretiyle büyük fırsatlar elde edilmektedir.

\section{KAYNAKLAR}

Graban, M. (2011). Yalın Hastane. (Çeviren: Şengözer P.), Optimist Yayınları, İstanbul. Institute for Healthcare Improvements (2005). Going Lean in Healthcare: Innovation Series 2005, No 7. Cambridge, Mass: Institute for Healthcare Improvement.

Özkan, O., Bayın, G., \& Yeşilaydın, G. Sağlık Sektöründe Yalın Tedarik Zinciri Yönetimi.

Şimşir, İ., Bağış, M., Kurutkan, M. N., \& Oğuz, B. (2013). Sağlık Hizmetlerinde İsraf Yönetimi. IV. Uluslararası Sağlıkta Performans ve Kalite Kongresi, Ankara, 02-04.

Tengilimoğlu, D., \& Yiğit, V. (2013). Sağlık işletmelerinde tedarik zinciri ve malzeme yönetimi. Ankara: Nobel Yayın Dağıtım. 
Timur, M. N., \& Başkol, M. (2013). Tedarik zinciri yönetimi. M. N. Timur \& G. S. Çekerol (Edt.), Tedarik zinciri yönetimi içinde (s. 25---- 46). Eskişehir: Anadolu Üniversitesi Açıköğretim Fakültesi Yayınları.

Tutuncu, O., \& Kucukusta, D. (2008). The role of supply chain management integration in quality management system for hospitals. International Journal of Management Perspectives, 1(1), 31-39.

Yıldız, S., Yalman F., (2015). “Sağlık işletmelerinde Yalın Uygulamalar Üzerine Genel Bir Literatür Taraması”. Uluslararası Sağlık Yönetimi ve Stratejileri Araştırma Dergisi, Cilt: 1, Sayı: 1.

Willats P., http://www.lean.org.tr/neden-yalin-hastaneler-kurmaliyiz/. Yalın Enstitü, Türkiye.

http://www.dergil.com/tr/dergi/nisan-mayis-2007/yatay-entegre-is-modeli-olarak-yalin-tedarik-zinciri-yonetimi/177.aspx. erişim tarihi; 21.08.2015.

http://www.dergil.com/tr/dergi/kasim-aralik-2011/tedarik-zincirinin-sifir-noktasi-satin-alma/414.aspx, erişim tarihi; 28.08.2015.

http://www.satinalmadergisi.com/2014/07/04/tedarik-zinciriniz-yalin-mi/ Erişim Tarihi : 11.08.2015 